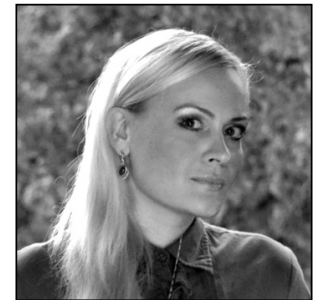

Kerttu Mäger

\title{
Enforcing the Judgments of the ECtHR in Russia in Light of the Amendments to the Law on the Constitutional Court
}

\section{Introduction}

This article discusses problems related to implementing the judgments of the European Court of Human Rights (ECtHR) in Russia. Although the contracting parties are obliged to execute the judgments of the ECtHR and are required to take all measures necessary to advance implementation ${ }^{{ }^{* 1}}$, there are serious problems with enforcing the judgments in several member states. The binding role of the ECtHR's judgments is subject to doubts and questioning and, occasionally, an outright rejection ${ }^{, * 2}$. Russia is one of nine countries highlighted in the report of the Parliamentary Assembly of the Council of Europe (the PACE report) on implementing the judgments of the ECtHR as having the highest number of non-implemented judgments. ${ }^{*} 3$ As many as 1,474 cases were waiting for execution in Russia as of the beginning of $2015^{* 4}$, and it takes, on average, 9.7 years to implement a judgment of the ECtHR in Russia. ${ }^{*}$ Russia has a 'long list of outstanding issues concerning implementation of judgments of the European Court of Human Rights, most of which concern particularly serious human rights violations', according to the PACE report. ${ }^{* 6}$ Several structural problems contribute to the high number of Russian cases discussed by the ECtHR and the unsatisfactory implementation of judgments. These include non-enforcement of domestic judicial decisions, violation of the principle of legal certainty, a 'supervisory review procedure' (надзор) that allows reopening of the final and enforceable judgments, poor conditions in detention on remand, torture and ill treatment in police custody, the actions of the security forces in the North Caucasus, various violations related to secret extradition

1 See the Parliamentary Assembly's report 'Implementation of Judgments of the European Court of Human Rights', doc. 13864, 9.9.2015, para. 53. Available at http://assembly.coe.int/nw/xml/XRef/Xref-DocDetails-EN.asp?fileid=22005 (most recently accessed on 1.7.2016).

2 W. Sadurski. Partnering with Strasbourg: Constitutionalisation of the European Court of Human Rights, the accession of Central and East European States to the Council of Europe, and the idea of pilot judgments. - Human Rights Law Review 2009 (9) / 3, p. 405.

3 Other countries include Bulgaria, Greece, Hungary, Italy, Poland, Romania, Turkey, and Ukraine. For further information, see the PACE report (Note 1), p. 3.

4 According to the data of the Committee of Ministers report 'Supervision of the execution of judgments of the European Court of Human Rights - Annual Report 2014', the countries with the largest numbers of unimplemented ECtHR judgments are Italy (2,622 cases), Turkey (1,500 cases), and the Russian Federation (1,474 cases).

5 PACE report (see Note 1), para. 31.

6 Ibid., para. 17. 
to former Soviet republics in central Asia, and prohibition of LGBT assemblies. ${ }^{*}$ As is argued by Klaas de Vries, a rapporteur with the PACE Committee on Legal Affairs and Human Rights, persisting problems with implementation of various judgments demonstrate 'a clear lack of political will to execute the Court's judgments and to follow the Committee of Ministers' recommendations'. ${ }^{*}$ The relationship between Russia and the Council of Europe (hereinafter 'CoE') has always been 'marked by a profound contradiction"*9. It can be agreed that, on account of the multi-layered legal order that exists in Europe today, tensions between individual layers of the European legal order are unavoidable ${ }^{*_{10}}$. Most probably, the tensions between the ECtHR and Russia reached their peak when, in December 2015, Russia adopted a law"11 ('The Amended Law on the Constitutional Court') refusing to acknowledge the binding force of the ECtHR's judgments and empowering the Constitutional Court of the Russian Federation to declare said judgments unenforceable when implementation would be in conflict with the Constitution of Russia. The aim of the current paper is to analyse the enforceability of the judgments of the ECtHR in Russia, considering certain amendments to the Law on the Constitutional Court and relevant case law of the Constitutional Court, and to assess the regulatory changes and court practice from the perspective of obligations Russia has undertaken as a member of the CoE.

\section{Enforceable judgments as the ECtHR's main strength}

The ECtHR has been praised as the strongest and the most efficient oversight system in international human rights law ${ }^{* 12}$, 'a crown jewel of the world's most advanced international system for protecting civil and political liberties" ${ }^{*} 13$. The associated supranational enforcement mechanism, which enables citizens, often disadvantaged in their home countries, to enforce their rights at the international level, is regarded as the main strength of the European Convention on Human Rights $\left(\mathrm{ECHR}^{*}{ }^{*}\right){ }^{*}{ }^{*}{ }^{15}$ From the perspective of citizens, the ECtHR is often 'a last chance of securing redress for abuses they have suffered at the hands of their government ${ }^{* * 16}$. The mechanism for individual petitioning is supposed to help "bridge the gap between the lofty goals of international human rights law and the imperfect execution of human rights norms at the national and local levels ${ }^{*{ }^{*} 17}$. Successful and expeditious implementation of the judgments of the ECtHR on the national level is vital for the ECtHR, as both the credibility and the legitimacy of the system depend on it. ${ }^{* 18}$ However, co-operation within the $\mathrm{CoE}$ in accordance with its goals and standards and also implementation of the rights under the Convention and the decisions of the ECtHR remain the duty and opportunity of governments. For its effectiveness, the CoE system ultimately relies on 'the good will of nation-states whose commitment to the ECHR system is based on traditional, international-law type of obligations'. ${ }^{19}$

Ibid., para. 13.3 .

$8 \quad$ Ibid., para. 17.

9 J.-P. Massias. Russia and the Council of Europe: Ten years wasted? - Russie. Nei. Visions 2008/15 (translated from French by Nicola Bigwood), p. 4.

10 European Commission for Democracy through Law (the Venice Commission). Opinion No. 832/2015: Interim opinion on the amendments to the Federal Constitutional Law 'On the Constitutional Court' of the Russian Federation. CDL-AD(2016)005. 15.3.2016, Strasbourg, para. 59 (hereinafter 'the Venice Commission').

11 Federal constitutional law from 14 December 2015, No. 7-FKZ, 'On amending the federal constitutional law "On [the] Constitutional Court of the Russian Federation"'.

12 S. Sweet. A cosmopolitan legal order: Constitutional pluralism and rights adjudication in Europe. - Global Constitutionalism 2012/1, p. 53. - DOI: http://dx.doi.org/10.1017/S2045381711000062.

13 L.R. Helfer. Redesigning the European Court of Human Rights: Embeddedness as a deep structural principle of the European human rights regime. - European Journal of International Law 2008 (19) / 1, p. 125.

14 In this article also referred to as 'the Convention'.

15 R.A. Cichowski. Civil society and the European Court of Human Rights. - J. Christoffersen, M.R. Madsen (eds). The European Court of Human Rights between Law and Politics. Oxford: Oxford University Press 2011, p. 79. See also C. Hillebrecht. Implementing international human rights law at home: Domestic politics and the European Court of Human Rights. - Human Rights Review 2012/13, pp. 279-301. - DOI: http://dx.doi.org/10.1093/acprof:0so/9780199694495.003.0005.

16 C. Schreck. Russian Law on rejecting human rights courts violates Constitution, experts say. Radio Free Europe, 16.12.2015. Available at http://www.rferl.org/content/russian-law-on-rejecting-human-rights-courts-violates-constitution-experts-say/27432125.html (most recently accessed on 1.7.2016).

17 C. Hillebrecht. (see Note 15), p. 279.

18 D. Anagnostou, A. Mungiu-Pippidi. Domestic implementation of human rights judgments in Europe: Legal infrastructure and government effectiveness matter. - European Journal of International Law 2014 (25) / 1, p. 206.

19 W. Sadurski (see Note 2), p. 399. 
Under Article 46 (1) of the ECHR, the contracting parties undertake to abide by the final judgment of the ECtHR in any case to which they are parties. State bodies have an obligation to 'comply with the legal situation under the ECHR but also to remove all obstacles in their domestic legal system that might prevent an adequate redress of the applicant's situation ${ }^{{ }^{*} 20}$. States can choose among the means of execution they consider to be appropriate; however, 'the State does not have the choice to execute or not to execute, [and] that choice is limited only to the means of execution'. ${ }^{{ }^{21}}$ Compliance with the final judgment covers redress in the individual case at hand, but, in addition, the state may be required to revise its legislation or to reform its administrative or judicial practice in order to render its legal system in conformity with the ECHR. ${ }^{* 2}$ Notwithstanding the flexibility granted to the states in choosing appropriate means of execution, problems with implementation remain in several member states, including Russia.

\section{The position of the ECHR and the judgments of the ECtHR in the Russian legal system}

\subsection{Changing interpretation by the Constitutional Court}

Pursuant to Article 15 (4) of the Russian Constitution, the universally recognised norms of international law and the international treaties and agreements of the Russian Federation shall be a component part of the country's legal system. If an international treaty or agreement of the Russian Federation fixes other rules than those envisaged by law, those rules of the international agreement shall be applied. Since Russia ratified the ECHR in 1998, it has been an integral part of the Russian legal system. However, as the interpretation of Article 15 (4) has differed considerably from one time period to another, also the position of the ECHR in Russia's legal system has been a highly disputed question among Russian legal scholars and in the practice of the Constitutional Court.

In the first years following the ratification of the ECHR, the approach to the Convention was generally favourable. In 2001, the Constitution Court established that the decisions of Russia's institutions must be in accordance with the ECtHR. ${ }^{*}{ }^{23}$ However, according to an interpretation by the Constitutional Court in 2007, the words 'are part of its legal system' in Article 15 (4) of the Constitution mean simply that 'international agreements, including the Convention and decisions of the ECtHR, should only be taken into account in passing decisions' (italics in the original). ${ }^{*} 4$ This indicates a negative turn with regard to the role of the Convention and the ECtHR in the Russian legal system. Russian human rights lawyer Kirill Koroteev explains: 'In Russian law, the words take into account have a clear meaning: that which should be taken into account is not obligatory' (italics in the original). ${ }^{*} 5$

Over the past few years, the ECtHR has issued several judgments against Russia in politically sensitive cases, which have received strong disapproval in Russia ${ }^{*}{ }^{26}$ and have resulted in an increasing reluctance to execute of judgments of the ECtHR. The president of the Constitutional Court, Valery Zorkin, has criticised the ECtHR for exhibiting more and more pronounced judicial activism and orientation toward revealing structural defects of national legal systems. ${ }^{*} 2$ According to Zorkin, the ECtHR does not give sufficient recognition to the socio-historical context of the various individual countries. He argues:

Judgment of the European Court of Human Rights in Maestri v. Italy, Application 39748/98 from 17 February 2004, para. 47.

$21 \quad$ Venice Commission (see Note 10), para. 57.

22 Ibid., para. 55.

23 K. Koroteev. The European factor in Russian justice. Open Democracy News Analysis, 26 June 2008. Available at https:// www.opendemocracy.net/node/45245/pdf (most recently accessed on 1.7.2016).

24 Ibid.

25 Ibid.

26 For example, the Grand Chamber's judgment of October 2010 in Markin $v$. Russia triggered a strong backlash within Russia. See, e.g., L. Mälksoo. Markin v Russia. - The American Journal of International Law 2012 (106) / 4, pp. 836-842. Controversial cases also include the ECtHR's Anchugov and Gladkov v. Russia, of 4 July 2013 (applications 11157/04 and 15162/05), involving prisoners' right to vote, and OAO Neftyanaya Kompaniya Yukos v. Russia, of 24 June 2014 (application No. 14902/04).

27 V.D. Zorkin. Challenges of implementation of the Convention on Human Rights. Presentation at the international conference on 'enhancing national mechanisms for effective implementation of the European Convention on Human Rights', held 
The significance of more full consideration of a particular socio-historical (socio-cultural) context of the Convention's realization by the European Court can be demonstrated by the widely known case 'Konstantin Markin v Russia" ${ }^{\text {"* }}$, which became an impulse for Russia for elaboration of the role of the Constitutional Court of the Russian Federation in the mechanism of implementation of the Convention. ${ }^{*} 9$

On 6 December 2013, considering the implementation of the judgment in the controversial case Konstantin Markin v. Russia, the Constitutional Court held that when a judgment of the ECtHR contradicts a prior ruling of the Constitutional Court on the case in question, the Russian Constitutional Court should have the final say in the execution of the relevant judgment by the ECtHR. The Constitutional Court explained that when a court of general jurisdiction has reopened proceedings in order to implement the judgment of the ECtHR and it cannot enforce that judgment of the ECtHR without at the same time disregarding provisions of domestic law, the court must suspend the proceedings and request the Constitutional Court to assess the constitutionality of such provisions. The Constitutional Court did not directly assess the place of the ECHR and judgments of the ECtHR in the Russian legal order; however, it held that when finding the challenged legal provisions to be in accordance with the Constitution, the Constitutional Court would determine possible constitutional means of implementation of the relevant judgment of the ECtHR within the limits of its competence. ${ }^{*}{ }^{30}$

In June 2015, when Russia had missed the deadline for submitting an action plan for just satisfaction awarded to shareholders of Yukos ${ }^{*}{ }^{31}$, the issue of the relationship between international law and national law was raised in the State Duma. Ninety-three Russian deputies asked the Constitutional Court for a clarification as to the constitutionality of several pieces of legislation, including the federal law titled 'On Ratification of the ECHR' and the federal law 'On International Treaties'. The deputies claimed that the contested regulations included provisions unconstitutionally obliging Russian authorities to implement the judgments of the ECtHR even when they are in conflict with the Russian Constitution. ${ }^{*}{ }^{32}$ According to Valery Zorkin, one of the reasons for this request was the judgment of the ECtHR in the case Anchugov and Gladkov v. Russia. ${ }^{*} 33$ In its judgment of 14 July 2015, the Constitutional Court ${ }^{*} 34$ held that the contested provisions were not actually unconstitutional. The Constitutional Court also explained that, in accordance with Article 46 of the ECHR, Russia 'recognized ipso facto and without special agreement the jurisdiction of the European Court of Human Rights as obligatory" ${ }^{*} 35$ and that the ECHR was an integral part of the Russian legal system. ${ }^{*}{ }^{36}$ However, despite those statements, the Constitutional Court concluded that, although the Russian Constitution and the ECHR are based on the same basic values, in the event of a contradiction between the two with respect to the rights and freedoms of man and citizen, preference should be given to the Constitution and therefore Russia is not obliged to follow the judgments of the ECtHR literally when the enforcement of the judgment would be contrary to Russia's constitutional values. ${ }^{*}{ }^{37}$ The Constitutional Court also stressed that the participation of the Russian Federation in any international treaty relationship does not mean giving up national sovereignty, that neither the ECHR nor the legal positions of the ECtHR based on it can cancel the priority of the Constitution, and that the implementation of international treaties and judgments of international organs is conditional upon these being in accordance with the Russian Constitution ${ }^{*} 38$ According to the Constitutional Court, when the ECtHR's interpretation of the provisions of the

in St Petersburg on 22-23 October 2015. Written notes available at http://www.ksrf.ru/en/News/Documents/Report\%20 for\%2022\%20October.docx (most recently accessed on 1.7.2016), pp. 2-3.

28

29

30 Judgment of the Russian Constitutional Court of 6 December 2013, No. 27-P.

31 See Committee of Ministers. Case against the Russian Federation (Case No. 18, 1230th meeting), 11 June 2015. Available at https://wcd.coe.int/ViewDoc.jsp?p=\&Ref=CM/Del/Dec\%282015\%291230/18\&Language=lanFrench\&Ver $=$ original\& Site=CM\&BackColorInternet=DBDCF2\&BackColorIntranet=FDC864\&BackColorLogged=FDC864\&direct=true (most recently accessed on 1.7.2016).

32 See Section 1, para. 5 of Judgment of the Russian Constitutional Court No. 21-P/2015, of 14 July 2015 (hereinafter 'Judgment No. 21-P/2015').

33 V.D. Zorkin (see Note 27), p. 11.

34 Judgment No. 21-P/2015

35 Ibid., Section 1, para. 1.

36 Ibid., Section 2.

37 Ibid., Section 4, para. 2.

38 Ibid., Section 2.2, paras 2 and 3. 
ECHR is not in accordance with the principles and norms of the Russian Constitution, Russia may in exceptional cases 'withdraw from the implementation of the obligations imposed on it, when such derogation is the only possible way to avoid violations of the fundamental principles and norms of the Constitution of the Russian Federation"*39. According to Zorkin in his capacity as president of the Constitutional Court, the latter ruling, 'as the previous judgment of 6 December, 2013 [...] is not sensational, because it only reproduces and develops the legal position on the supremacy of the Constitution of the Russian Federation when executing the ECtHR decisions. ${ }^{*}{ }^{40}$ However, an expert on Russian constitutional law, Maria Smirnova, argues that the ruling of the Constitutional Court 'clearly signifies a change in the political attitude towards the implementation of decisions of the European Court" 41 .

Placing the Russian Constitution at the apex of the hierarchy of norms within the Russian legal system was viewed by the Venice Commission as an internal rationale for the decision taken. ${ }^{*} 42$ At the same time, the external rationale is reflected in the position of the Constitutional Court according to which

[a]n international treaty is binding for its participants in the meaning which can be elucidated with the help of the adduced rule of interpretation [...] if the ECtHR, interpreting a provision of the ECHR [...] gives to a notion used in the Convention a meaning other than the ordinary one or carries out interpretation contrary to the object and purpose of the Convention, the state, in respect of which the judgment has been passed on this case, has the right to refuse to execute it as it goes beyond the obligations, voluntarily taken by this state upon itself when ratifying the Convention. ${ }^{*} 43$

The Constitutional Court also stressed that, from the principles of interpretation set forth in the Vienna Convention on the Law on Treaties, when the interpretation of the ECtHR diverges from the imperative norms of customary international law (jus cogens), including the principle of sovereignty and the principle of noninterference with internal affairs of states, one can derive the conclusion that execution of the judgment is not obligatory. ${ }^{*} 44$ The Constitutional Court concluded that decisions of an authorised interstate body, including judgments of the European Court of Human Rights, cannot be executed 'if the interpretation of the provisions of an international treaty, that this decision is based on, violates relevant provisions of the Constitution of the Russian Federation.. 45 Therefore, proceeding from the positions of the Constitutional Court, one can conclude that, although Russia has voluntarily become a member of the CoE and has subjected herself to the jurisdiction of the ECtHR, whenever a judgment of the ECtHR infringes the principle of sovereignty or is in conflict with the Constitution of the Russian Federation, Russia may refuse to implement that judgment.

It should be noted that the executive branch has a very important role in the process of refusing to implement the judgments of the ECtHR. Namely, when the government or the President of the Russian Federation consider a judgment of the ECtHR impossible to enforce for reason of a conflict with the Russian Constitution, at the request of these authorities the Constitutional Court should provide its interpretation. When the Constitutional Court concludes that the judgment of the ECtHR is incompatible with the Constitution, it shall not be implemented. The Constitutional Court also proposed that a special legal mechanism be created in order to ensure the supremacy of the Constitution in the implementation of ECtHR rulings. ${ }^{*} 6$ It is remarkable that the main conclusions of the Constitutional Court directly mirrored the position taken by the President's representative to the Constitutional Court, Mikhail Krotov. Although the presence of a President's representative on the Constitutional Court is highly questionable in terms of the principle of separation of powers, this has been the reality of Russia since 1996. ${ }^{*} 47$

Valery Zorkin has emphasised that ' $[t]$ he main problem, which the Constitutional Court of Russia has faced within its work, is the need of simultaneous fulfilment of two not always well-combined tasks: harmonizing Russia's legal system with the all-European legal expanse, on the one hand, and protection of its

Ibid., Section 2.2, para. 4.

40 V.D. Zorkin (see Note 27), p. 12.

41 M. Smirnova. Russian Constitutional Court affirms Russian Constitution's supremacy over ECtHR decisions, 15 July 2016. EJIL Talk!: Blog of the European Journal of International Law. Available at http://www.ejiltalk.org/russian-constitutional-court-affirms-russian-constitutions-supremacy-over-ecthr-decisions/ (most recently accessed on 1.7.2016).

42 Venice Commission (see Note 10), para. 18.

43 Translation of this section of the Judgment No. 21-P/2015 is taken from the report of Venice Commission (see Note 10), para. 22. For original text, see Section 3, para. 3 of Judgment No. 21-P/2015.

44 Section 3, para. 3 of Judgment No. 21-P/2015.

45 Ibid., Section 3, para. 9.

46 Section 1, paras 4 and 5 of the resolution part of Judgment No. 21-P/2015.

47 For further information, see M. Smirnova (see Note 41). 
own constitutional identity, on the other'.*48 Recent case law demonstrates that the Constitutional Court has found the necessary equilibrium in building its constitutional identity on the principle of sovereignty, overriding that part of its constitution declaring the supremacy of international law and thereby violating the international obligations that Russia has undertaken.

\subsection{Amendments to the Law on the Constitutional Court}

The decision of the Constitutional Court issued on 14 June 2015, analysed above, is also significant because mirroring this judgment almost point for point, in December 2015, the State Duma and the Federation Council approved the Amended Law on the Constitutional Court. Accordingly, the new legislation gives insight into how the Constitutional Court is likely to interpret the key terms of the law in the future. ${ }^{*} 9$ Pursuant to the Amended Law on the Constitutional Court, the Constitutional Court may consider the possibility of enforcement of the decision of an interstate body for the protection of human rights and freedoms at the request of the federal executive authority that is competent to operate in the field of protecting Russia's sovereign interests ${ }^{*} 5$. The regulation allows the Constitutional Court to decide whether the decision of an international court, such as the European Court of Human Rights, should or should not be enforced in Russia. Neither the ECtHR nor any other specific court is explicitly mentioned in the law; instead, the term 'an interstate body for the protection of the rights and freedoms of a person' (межгосударственный орган по защите прав $и$ свобод человека) is used. The Constitutional Court can consider the relevant case in order to resolve uncertainties as to the possibility of enforcing judgments of interstate bodies for the protection of human rights and freedoms when the interpretation of relevant treaties issued by these bodies is presumably in conflict with the Constitution of the Russian Federation ${ }^{*}{ }^{51}$. The Constitutional Court shall consider the case from the point of view of the constitutional order of the Russian Federation and the legal regulation of the rights and freedoms of man and citizen established by the Constitution of the Russian Federation. ${ }^{*}{ }^{2}$ If the Constitutional Court recognises the interstate body's ruling to be unenforceable, any action aimed at the satisfaction under the relevant decision cannot be performed ${ }^{*} 53$; hence, the decision will not be enforced in practice.

A report published by the Venice Commission is highly critical of the amended Law on the Constitutional Court, especially regarding its strict 'black or white approach'. They argue:

If the Constitutional Court cannot 'remove the uncertainty' about the contradiction between the Constitution and the international decision [...] no measures (acts) aimed at the enforcement of it may be taken (adopted) within the territory of the Russian Federation. The amendments thus adopt an 'all or nothing' solution: they move from the premise that possible conflicts have to be settled either through refusing the implementation of ECtHR judgments - which is inadmissible - or through declaring that there is no conflict between these judgments and the Russian Constitution, a 'black or white' alternative. ${ }^{*} 54$

On one hand, states are by no means obliged to use measures of execution that are unconstitutional in the respective country. ${ }^{*} 5$ According to the position of the Venice Commission, contradictions between national systems and rulings of the ECtHR are possible, but state bodies must find appropriate solutions for reconciling the provisions of the ECHR with the national constitution. This can be done effectively via means of dialogue, which has been successfully used between Germany and the ECtHR; through interpretation; or by means of reforms to national legislation. ${ }^{*}{ }^{6}$ However, the Amended Law on the Constitutional Court does not provide for the option that if a certain measure is not in accordance with the Russian Constitution, another measure should be chosen in order to reconcile the domestic law and the judgment of the ECtHR and enable implementation the relevant judgment. The law is 'very strict in firmly stipulating that the execution as a whole is blocked'.* 57

\footnotetext{
V.D. Zorkin (see Note 27), p. 1.

Venice Commission (see Note 10), paras 13, 25.

See Article $3^{2}$ of the Amended Law on the Constitutional Court.

See Article 36 (2) of the Amended Law on the Constitutional Court.

See Article $104^{3}$ of the Amended Law on the Constitutional Court.

See Article $104^{4}$ of the Amended Law on the Constitutional Court.

Venice Commission (see Note 10), para. 73.

Ibid., para. 83.

Ibid., paras 97, 100.

Ibid., para. 83.
} 
Another highly problematic aspect is that the amendments have weakened the position of Russian citizens in defending their rights. The possibility of declaring a judgment of the ECtHR unenforceable means also that the state can refuse payment of the just satisfaction rewarded to an applicant. Moreover, according to the amended Article 47 of the Law on the Constitutional Court, the Constitutional Court can reach its decision without holding a hearing. This means that the applicant is not able to present his or her arguments, even though being clearly affected by the decision to enforce or not to enforce the judgment of the ECtHR. This approach violates the principle of a fair trial. ${ }^{*}{ }^{8}$ As was observed by the Venice Commission, '[o]nly the position of the federal authority which submitted the complaint appears to be relevant, while the position of the people concerned may be formally disregarded'. ${ }^{59}$

An important criticism of the Amended Law on the Constitutional Court has been that, because the Russian Constitution clearly acknowledges the binding nature of international law and treaty obligations in its Article 15 (4), implementing the amended Law on the Constitutional Court is itself in conflict with Russia's constitution while also violating Russia's international treaty obligations. European Union constitutional law professor Dmitry Kochenov, at the University of Groningen, argues that, under Russia's constitution, treaties signed by Russia, the ECHR among them, are the 'supreme force in the land'. It is controversial that when, on one hand, the objective of the law is defending Russia's constitution, applying it would itself constitute a violation the Constitution. ${ }^{* 60}$ Bill Bowring, a professor of international human rights law at the University of London's Birkbeck College, agrees that the law contradicts the Russian Constitution, along with the country's 1998 law ratifying the European Convention on Human Rights. ${ }^{* 61}$

Andrei Klishas, the head of the Committee on Constitutional Legislation of the Federation Council, claims that the aim behind the law is to stimulate the government to implement the judgments of international courts, since under the new legislation they cannot independently decide whether or not to implement the decision and instead have to turn to the Constitutional Court. ${ }^{* 62}$ This statement obviously has no basis in either domestic Russian or international law, because the government itself does not have any grounds to refuse implementation; on the contrary, the government is obliged to secure implementation of the ECtHR judgments. Under Article 26 of the Vienna Convention on the Law on Treaties, states are bound to respect ratified international agreements. ${ }^{* 63}$ The Venice Commission takes the following position:

A possible declaration of unenforceability of a judgment of the European Court of Human Rights violates Article 46 of the European Convention on Human Rights, which is an unequivocal legal obligation and includes the obligation for the State to abide by the interpretation and the application of the Convention made by the Court in cases brought against it. ${ }^{*} 64$

An argument according to which judgments of the ECtHR should not be executed when the interpretation provided by the ECtHR is not in accordance with Russian constitutional principles is clearly not valid from the perspective of international law. Under Article 27 of the Vienna Convention on the Law on Treaties, the provisions of a state's internal law cannot be invoked to justify failure to perform the state's duties, and this is applicable in the context of the $\mathrm{ECHR}^{*} 65$.

Head of the Russian Constitutional Court Zorkin has argued that the Constitutional Court exercises the opportunity provided by the Amended Law on the Constitutional Court only when the Russian Constitution protects the rights of the citizens to a greater extent than the ECtHR does. ${ }^{* 66}$ According to the report of the Venice Commission, it is very unlikely that the ECtHR would find a violation to exist if the domestic legal order indeed provided for a higher level of protection. ${ }^{*}{ }^{6}$ The ECHR sets forth minimum standards, and countries are free to provide for a higher level of protection if they so wish. According to Article 53 of the

58 Ibid., paras 85, 101.

59 Ibid., para. 85.

60 As cited by C. Schreck (see Note 16).

61 Ibid.

62 Совет Федерации утвердил приоритет КС над решениями международных судов. 9.12.2015. Pravo.ru. Available at http://pravo.ru/news/view/124757/ (most recently accessed on 1.7.2016).

63 Venice Commission (see Note 10), para. 97.

64 Ibid., para. 99.

65 Ibid., para. 97.

66 Президент объяснил необходимость приоритета Конституционного суда над ЕСПЧ. Pravo.ru. 14.12.2015. Available at http://pravo.ru/news/view/124886/ (most recently accessed on 30.3.2016).

67 Venice Commission (see Note 10), para. 76. 
ECHR, '[n]othing in this Convention shall be construed as limiting or derogating from any of the human rights and fundamental freedoms which may be ensured under the laws of any High Contracting Party or under any other agreement to which it is a party'. Therefore, when Russian standards are higher than the standards of the ECHR, minimum standards must be followed and there should not be any grounds for the ECtHR to find a violation of the Convention.

\subsection{The ideas behind the Amended Law on the Constitutional Court}

The sovereignty of Russia can be seen as the guiding principle behind the new legislation and preceding judgments of the Constitutional Court. Alexander Manov, an assistant professor at Kutafin Moscow State Law University, has argued that '[i]ndeed, human rights are sovereign, but the state is sovereign too'. ${ }^{68}$ He views the Amended Law on the Constitutional Court as a precaution in case there are attempts to exert external pressure on Russia ${ }^{* 69}$. Also Valery Zorkin has stressed that 'interaction of the European and national legal orders is impossible in conditions of subordination"*70 and that the steps taken by the Constitutional Court are

based on the aspiration to safeguard ourselves from situations, fraught with serious complication of the relations of Russia with the ECtHR and with the Council of Europe as a whole. The question regards the situations when the ECtHR decisions, intruding into the sphere of the national sovereignty of Russia, are fraught with more substantial violations of rights of Russian citizens than those, which the Strasbourg Court is objecting to. ${ }^{*} 71$

The political relevance of the Amended Law on the Constitutional Court is 'underlined by the fact that the submission of the complaint of the federal authority before the Constitutional Court is seen as an aspect of the competence of that authority "for protecting the interests of the Russian Federation". ${ }^{72}$

The Amended Law on the Constitutional Court meshes well with the Russian concept of 'sovereign democracy', a creation of Vladislav Surkov"73. In a nutshell, such a Russian approach to democracy means that

democratic values are neither contested nor rejected [,] but subordinated to national interests. This logic is based on the refusal to undergo foreign supervision and meddling. Yet the decisions of the $\mathrm{CoE}$ are seen as such in Russia, and are thus a source of irritation and misunderstanding. ${ }^{*} 74$

\subsection{Implementation of the amended Law on the Constitutional Court}

On 2 February 2016, the Ministry of Justice lodged an appeal with the Constitutional Court in connection with the ruling of the ECtHR in the case Anchugov and Gladkov $v$. Russia, of 3 July $2013^{*}{ }^{*}$. This case is the first one in which the Constitutional Court will decide whether the execution of the decision of the ECtHR is in accordance with the Russian Constitution or not and, therefore, whether it shall be executed or not. The case pertains to the question of prisoners' voting rights. Applicants Sergey Anchugov and Vladimir Gladkov turned to the ECtHR with the claim that their right to vote had been violated. Both applicants were convicted of murder and other criminal offences and barred from voting in elections to the State Duma and in presidential elections, under Article 32 (3) of the Russian Constitution. The ECtHR held that the blanket ban on allowing prisoners to vote violated Article 3 of Protocol 1 of the ECHR, which provides for the right to free elections.

The case brought along extensive discussion among the legal scholars and practitioners in the field of human rights protection and as a novel step, several amicus curiae briefs were submitted to the

68 As cited by Yekaterina Sinelschikova. International courts' rulings no longer enforceable in Russia. Russia Direct, 10.12.2015. Available at http://www.russia-direct.org/russian-media/international-courts-rulings-no-longer-enforceable-russia (most recently accessed on 30.3.2016).

69 Ibid.

70 Ibid.

71 V.D. Zorkin (see Note 27), p. 14.

72 Venice Commission (see Note 10), para. 86.

73 See, e.g., В. Сурков. Национализация будущего: параграфы про суверенную демократию. - Эксперт. 2006 (12) / 6.

74 J.-P. Massias (see Note 9), p. 14.

75 Anchugov and Gladkov v. Russia [2013] ECtHR, applications 11157/04 and 15162/05 (4 July 2013). 
Constitutional Court by distinguished experts ${ }^{*} 76$. The legal scholars advised in their amicus curiae brief ${ }^{*} 77$ that the Constitutional Court should decide not whether compliance of the Russian Federation with its obligation to execute judgments of the ECtHR is possible or impossible but, instead, whether a particular method of execution of the judgments is possible or impossible from the perspective of the Constitution. They argued that the conflict between the provisions of Article 3 of Protocol 1 of the Convention and Article 32 (3) of the Constitution can and should be resolved by the Constitutional Court by means of interpretation of this constitutional provision allowing the establishment of a higher standard of human rights and freedoms in harmony with the requirements of the Convention. Experts explained that such an approach is dominant in European legal systems and, additionally, is well established in the practice of the Constitutional Court. For example, the Constitutional Court followed this approach when discussing the issue of carrying out the death penalty in Russia and decided to establish a moratorium on the death penalty, taking into account the special nature of international obligations Russia has undertaken and, secondly, the evolution of international legal standards of human rights. They advise taking similar factors into account in the consideration of Anchugov and Gladkov v. Russia. As can be seen, the experts' recommendations to overcome the conflict between Russian domestic law and the provisions of Protocol 1 of the ECHR are very much in line with the positions of the Venice Commission discussed above.

\section{Conclusions}

Although Article 46 of the ECHR does not leave room for 'cherry-picking' in enforcing the judgments, the Constitutional Court has suggested that Russian authorities should indeed engage in cherry-picking and enforce only those judgments that are proved to be in accordance with the Russian Constitution as interpreted by the Constitutional Court. The Constitutional Court has clearly expressed its view of the role and meaning of the ECHR and ECtHR in the Russian legal system as being contingent on approval by the Constitutional Court. Instead of this all-or-nothing approach, conflicts between the domestic legislation and the ECHR could be resolved through interpretation and dialogue, as advised by the Venice Commission and also by Russian legal experts. Although at the time of writing, the Constitutional Court has not yet declared any ECtHR judgments unenforceable, when deciding that, for reasons of conflict with Russian constitutional principles, the Anchugov and Gladkov $v$. Russia judgment or any other judgment is impossible to implement, Russia would clearly violate its obligations under the ECHR. Such conduct is unprecedented in the CoE, but it might be a threatening example for other countries to follow. The amended Law on the Constitutional Court poses a threat to the effectiveness of the ECtHR and creates an even greater stumbling block to dialogue between Russia and the ECtHR. It can severely harm the protection of rights and freedoms of Russian citizens and access to the protection provided via the ECHR. Still, as the majority of the ECtHR's judgments are not politically sensitive, there is a great chance that the authorities in Russia will not apply the mechanisms provided by the amended Law on the Constitutional Court in a substantial number of cases and will continue to enforce the international judgments.

\footnotetext{
76 One amicus curiae brief was submitted by experts of Institute for Law and Public Policy (http://ilpp.ru/en/), a Moscow based independent NGO, one of the leading Russian think tanks conducting research, educational activities and publishing in the sphere of constitutional law and another by group of legal scholars: G.I. Bogush, an assistant professor of criminal law and criminology at the law department of Lomonosov Moscow State University; K.I. Degtyarev, lecturer at the School of Law and Social Justice of Liverpool University (United Kingdom); G.A. Esakov, a professor and head of department of criminal law at Higher School of Economics; M.T. Timofeev, lecturer at the law faculty of the European Humanities University (Lithuania). See, for further information: Институт права и публичной политики. Заключение о толковании статьи 32 (часть 3) Конституции Российской Федерации для целей определения возможности исполнения постановления Европейского Суда по правам человека от 4 июля 2013 года по делу «Анчугов и Гладков против Российской Федерации». 28.03.2016. Available: http://www.ilpp.ru/netcat_files/userfiles/Litigation_Treinings/2016\%20Amicus\%20Curiae\%20Brief\%20(Anchugov\%20i\%20Gladkov).pdf (most recently accessed on 1.7.2016) and Г.И. Богуш, К.И.Дегтярёв, Г.А Есаков, М.Т.Тимофеев. Письменные соображения по существу дела, касающегося запроса Министерства юстиции Российской Федерации о разрешении вопроса о возможности исполнения Постановления Европейского Суда по правам человека от 4 июля 2013 года по жалобам №№ 11157/04 и 15162/о5 «Анчугов и Гладков против Российской Федерации». 23.03.2016. Available at http://chr-centre.org/wp-content/uploads/2016/o3/Anchugov-and-Gladkov-Amicus-Brief.pdf (most recently accessed on 1.7.2016).

77 Г.И. Богуш et al. (See note 76.)
} 